\title{
Geometrical analysis of Palesch family chapel in Kl'ačno, former Gaidel in Western Slovakia.
}

\author{
Zuzana Grúňová $^{1, *}$, Michaela Holešová $^{2}$ \\ ${ }^{1}$ Department of Building Engineering and Urban Planning, Faculty of Civil Engineering, University \\ of Žilina, Univerzitná 8215/1, 01026 Žilina, Slovakia \\ ${ }^{2}$ Department of Structural Mechanics and Applied Mathematics, Faculty of Civil Engineering, \\ University of Žilina, Univerzitná 8215/1, 01026 Žilina, Slovakia
}

\begin{abstract}
Oval and elliptic spaces are one group of central plans, used mainly in sacral architecture and palaces. Paper deals with geometrical analysis of one of the smaller representatives of the neoclassical sacral architecture with oval plan - Palesch family chapel of Virgin Mary in village Klačno in Western Slovakia. Oval and elliptic forms are not so often used in Slovak historical architecture and they are almost always connected with foreign influence and knowledge brought form Vienna, Paris, Pest, Eger and other education and praxis localities of the builder or architect. This uncommon oval form used in the small chapel is therefore certainly of interest from the point of view of architecture and geometry.
\end{abstract}

\section{Introduction}

Oval and elliptic spaces in architecture start to appear in the 15th - 16th cent. and evolution of forms continued with refinement of geometric constructions and broadening of mathematical knowledge. Baroque central sacral and hall spaces were the most inventive demonstration of this progress. Oval, circular and elliptic central spaces continued as a part of architectonical vocabulary in Slovakia also in the following periods of neoclassicism and historicist styles, but only few examples of fully developed large spaces with curvilinear forms could be found here and it is therefore a surprise, that oval was chosen for a small chapel. Fine form and well thought proportions are the most certainly connected with person of highly educated Georg Palesch. Further research in the archive of Spiš Diocese in Spišská Kapitula will be able to confirm hypotheses about construction and bring maybe even original drawings and name of author, who is unknown at the present.

\section{Village Kl'ačno, its history and architecture of the chapel}

Village Kl'ačno with population of 1100 inhabitants situated in Prievidza district, Trenčín region in the western Slovakia, surrounded by Strážovské mountains, most of the dwellings

*Corresponding author: grunova@fstav.uniza.sk 
lie in the narrow valley of Nitra river. Village was founded in the 13th cent. (the first mention in 1413 as Gaydel). It was mostly occupied by German catholic inhabitants, only after the WWII Slovaks become a majority. Name Gaydel (Gaÿdiell ad Baÿmocz[1], Gaydelehota) remained together with Hungarian name Nyitrafö (1913) up to 1948, when village got name Kl'ačno. Village is rich in term of historical buildings comparing to the size of the settlement - Roman catholic church with preserved renaissance constructions (built 1464) and two chapels (baroque from 1777 and neoclassical from 1824). Patron of the analysed monument - Chapel of Virgin Mary - was Juraj Palesch - Georg Palesch[2], born 1753 in Gaidel (Kl’ačno) died 1833 in Zipser Kapitel (Spišská Kapitula) [3,4]. He was a roman catholic priest, teacher and pious writer, known as a deeply educated and enlightened personality who founded schools and foundations for education promotion[5]. Palesch founded school also in Kl'ačno (built 1829) and decided to built here chapel of Virgin Mary, dedicated to memory of his deceased parents (both born and lived in Kl'ačno). About the period the construction of Palesch family Chapel in Kl'ačno, that was in the year of 1824 according to[6], village had 254 houses with 1774 inhabitants.

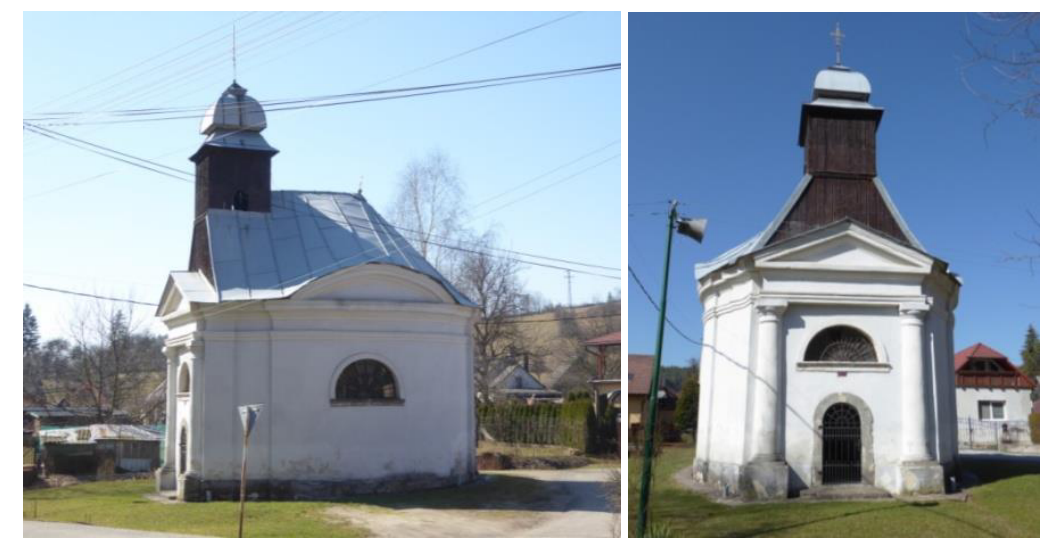

Fig. 1. Exterior of the Palesch Family chapel of Virgin Mary in Kl’ačno. Photo R. Kollárová, 2015.

Chapel was built in the neoclassical style in 1824. It is oval in the plan, rather small building decorated with pilasters and portico with wooden bell tower in the exterior and disproportionally large built-in organ gallery (added in 1827 according to inscribed cartouche "ANNO $1827 \mathrm{JT}$ " on organ encasement) in the interior. Building was not profoundly altered up to date - geometry analysis could be conducted at the original proportions (original masonry shape, volume). Roofing replacement and minor renovations were realized in 1905, 1927. Renovation together with waterproofing and humidity control works were realized in 1995 (project of Ing. M. Pichová). [7]

\section{Geometrical analysis of chapel}

\subsection{Module consideration and measurement units}

Compact mass of the chapel shows clearly well thought proportion ratios indicating primary geometric construction. The very first step in geometric analysis was a search for modularity in plan of structure. Square raster was used with various modules. The most striking was coordination of the most important structural points of chapel with module 600 
by $600 \mathrm{~mm}$ (fig.2.). Intersections coincide with regulation, main points of circle sections describing curvilinear complex plan. Rectangle circumscribing the main oval/elliptic space is constructed in the ratio 6:9 (approx. 3600 by $5400 \mathrm{~mm}$ ). Also other main axes and lines lie very closely to or at the modular net - e.g. centres of pillars on the main facade, centres of the concave chamfering between main mass and portico entrance etc.

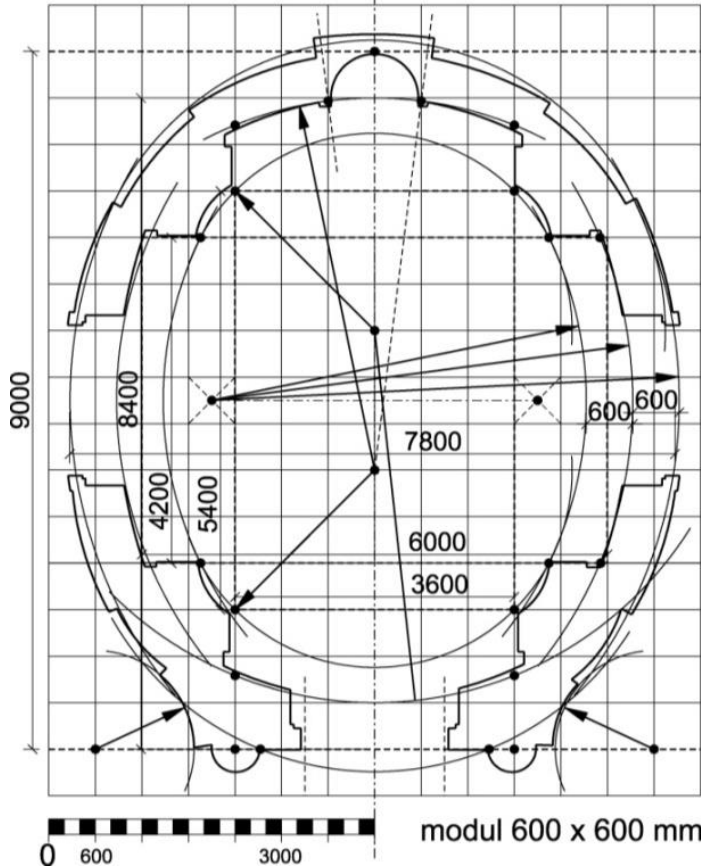

Fig. 2. Analysis of possible modular net applied to plan of the chapel.

Modularity close to 300 or $600 \mathrm{~mm}$ would be logical, because of the most probably used measurement units of the Austrian Empire - the Vienna fathom ((KI) $6 \mathrm{ft}=1896 \mathrm{~mm})$ and its fraction - foot, Fuß Another system of units that could be used is Roman cubit (römische Elle), Roman foot (pes), Vienna cubit (Wiener Elle) or German elbow (elle). Any system used would be approximation of human proportions. Further analysis of historical measurement units depends on if original plans could be found in the future. Also overall mass of the chapel structure is so small comparing to the possible observational error and deviations caused by building process, that it is impossible to relevantly proof difference between possible historical measurement units.

Table 1. Deviations of the multiples of historical units comparing to measurements in $\mathrm{mm}$.

\begin{tabular}{|c|c|c|c|c|c|c|c|}
\hline & $\mathrm{mm}$ & multiple & width & deviation & multiple & length & deviation \\
\hline $600 \mathrm{~mm}$ & & $\mathbf{6}$ & 3600 & $\mathbf{0 , 0 0} \%$ & $\mathbf{9}$ & 5400 & $\mathbf{0 , 0 0} \%$ \\
\hline Vienna ft & 316.080 & $\mathbf{1 1 , 5}$ & 3634.92 & $\mathbf{0 , 9 7} \%$ & $\mathbf{1 7}$ & 5373.36 & $\mathbf{0 , 4 9} \%$ \\
\hline Roman cubit & 444.000 & $\mathbf{8}$ & 3552 & $\mathbf{1 , 3 3} \%$ & $\mathbf{1 2}$ & 5328 & $\mathbf{1 , 3 3} \%$ \\
\hline Roman foot & 296.352 & $\mathbf{1 2}$ & 3556.224 & $\mathbf{1 , 2 2} \%$ & $\mathbf{1 8}$ & 5334.34 & $\mathbf{1 , 2 2} \%$ \\
\hline Vienna cubit & 779.300 & $\mathbf{4 , 5}$ & 3506.85 & $\mathbf{2 , 5 9} \%$ & $\mathbf{7}$ & 5455 & $\mathbf{1 , 0 2} \%$ \\
\hline German elle & 600.000 & $\mathbf{6}$ & 3600 & $\mathbf{0 , 0 0} \%$ & $\mathbf{9}$ & 5400 & $\mathbf{0 , 0 0} \%$ \\
\hline
\end{tabular}


Dimensions like width of the masonry could be attributed to the dimension of the brick used. In this case it is brick 55 by 285 by $135 \mathrm{~mm}$, with plastic inscription CFP - signature means COMES FRANCISCUS PALFFY. Bricks were produced in the kiln of Palffy Bojnice estate in the first third of the 19th century. This kind of bricks can produce wall thickness as a multiple of approx. $150 \mathrm{~mm}$.

\subsection{Hypothesis A - Ellipse was used in construction drawing and on site}

Elliptic constructions are rather common in technical praxis, mainly because of its interesting properties - sum of distances between any point on the ellipse to each of its focuses is constant. But it is not so easy to draw. Various drawing aids were invented to help the process of drawing an elliptic forms in technical design. One of the oldest so called "ellipsographs" originated from the idea of ancient Greek trammel of Archimedes (maybe even from Proclus time). Later on this idea was transformed into many simpler or more sophisticated variations. One of them, based on ellipsograph of Guidobaldo del Monte is described in [1]. Description only deals with mechanism and author took as already clear, that final drawing is really ellipse in the geometrical sense. Proof is in fact already implicated by the means of construction of the mechanism.
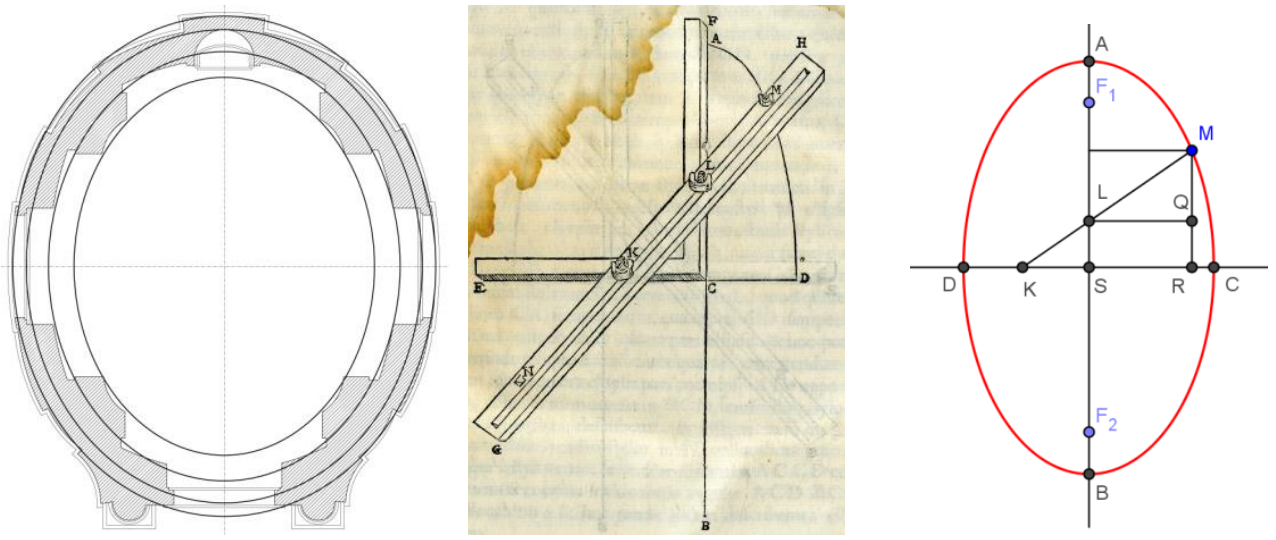

Fig. 3. Left are ellipses superimposed on the chapel's plan, drawn by Grúňová, in the middle is L'ellissografo, Planisphaeriorum universalium theorica, Pesaro 1579 presented in [8]. Right is geometric reconstruction of L'ellissografo created by Holešová.

Ellipsograph consists of two long flat boards, perpendicular to each other with length not shorter than length of minor axis of the ellipse. Third part is movable flat board with two sharp points - two screws, marked as K, L see fig. 3 that could be moved on it and fixed in the distances $a$ and $a-b$ ( $a$ is equal to the major axis and $b$ is equal to the minor axis of the ellipse) from the drawing end $\mathrm{M}$, which will inscribe ellipse. It is clear that distance $|\mathrm{LM}|=$ $b$. Points K, L are fixed on the third board, but they have to be fluently movable along two basic perpendicular boards, so $\mathrm{K}$ is movable along board with points $\mathrm{C}, \mathrm{D}$ and $\mathrm{L}$ is movable along board marked by A, B. End point $\mathrm{M}$ will describe the ellipse during motion, what can be easily proved. From the similarity of the triangles $\triangle \mathrm{KRM}$ and $\triangle \mathrm{LQM}$ and at the designation $|\mathrm{KS}|=v,|\mathrm{SR}|=x,|\mathrm{RM}|=y$ is

$$
\frac{v+x}{a}=\frac{x}{b}
$$


We have for the rectangular triangle $\triangle K R M$ and the lengths of its sides that

$$
(v+x)^{2}+y^{2}=a^{2}
$$

Equations (1) and (2) show that $\frac{x^{2}}{b^{2}}+\frac{y^{2}}{a^{2}}=1$ and point $M$ is already located on an ellipse whose centre is at point $\mathrm{S}$ and the length of the major and minor axis are $a$ and $b$, because $x$ and $y$ are the coordinates of $\mathrm{M}$.

\subsection{Hypothesis B - Mandorla and pole-rope method on site.}

Mandorla (also called Vesica Piscis) is geometrical shape also often with symbolical meaning, used in the medieval European art and architecture, but with an ancient origin. Simply constructed as intersection of the two same circles with centres on their radiuses. Intersection is almond shape with symbolical meaning of origin of life. Combination of two mandorlas with their axis oriented perpendicularly is called "Eye of the God". Mandorla is simple construction, easily drawn using poles and rope, therefore practical for building site construction.
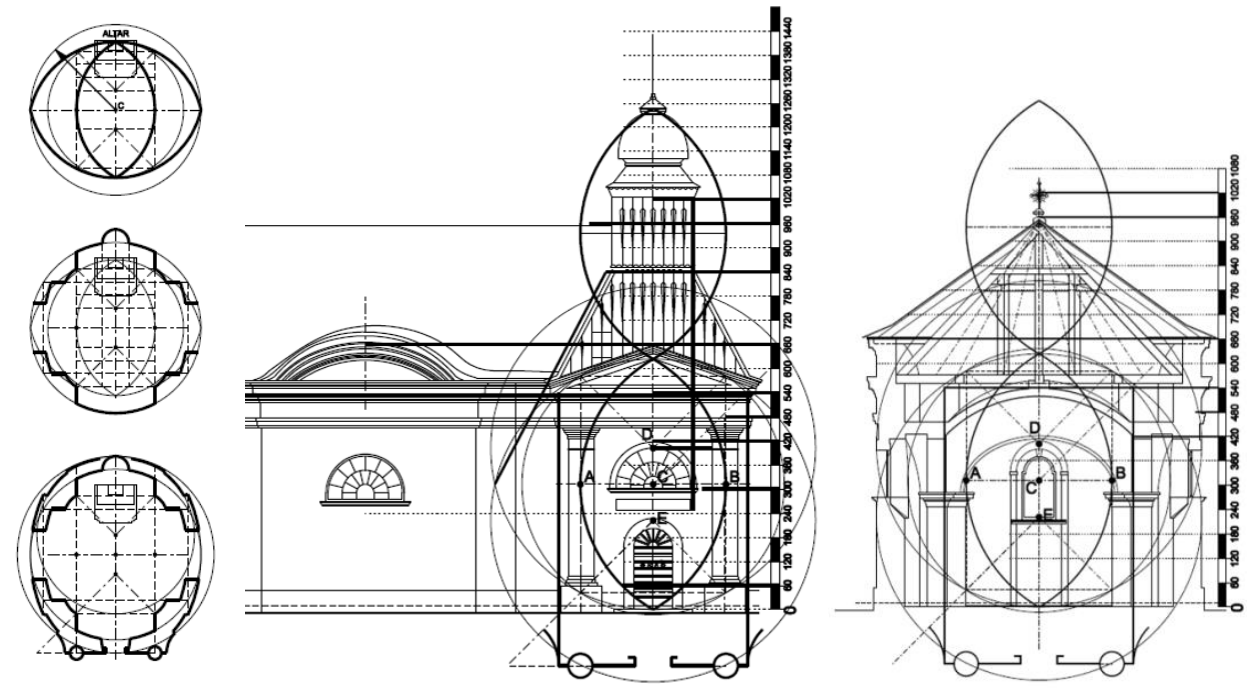

Fig.4. Oval constructions by Serlio. Source [3] redrawn by Grúňová

All of the points of the mandorla based geometrical construction are derived from two points of origin A and B with distance of approximately $3600 \mathrm{~mm}$, that create a hypotenuse of the first smaller mandorla. All derived points could be drawn using circles or their section and divisions of segments to 2 or 3 parts. Construction of the "God's eye" is modified, more "rounded" - bigger mandorla has centres of its circles at the points with the distance of $1 / 6$ from endpoints of smaller mandorla hypotenuse. Length of basic segment A, B close to $3600 \mathrm{~mm}$ also means transfer of hypothetic module close to $600 \mathrm{~mm}$ to all derived distances. The same mandorlas could be attributed to position of important points of exterior architecture of the Chapel. 


\subsection{Hypothesis C - Oval based construction and pole-rope method on site.}

Commonly used approximation of the ellipse are various oval shapes consisting of combination of the arcs - more easy to construct basic oval and parallel smaller and bigger oval arcs. The most famous geometrical constructions of oval (used also in baroque and later) are Serlio's two-centre ovals. (fig.5).
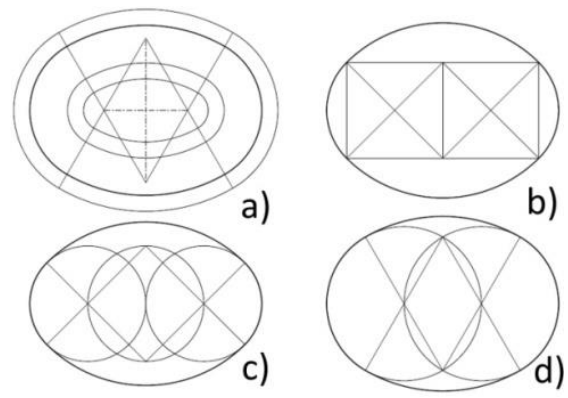

Fig.5. Oval constructions by Serlio. Source [9] redrawn by Grúňová

All these constructions retain the length of the major axis for the given ellipse. Ellipse is approximated by these constructs and for constructions (b) to (d) the length of the major axis gives the length of the minor axis. If we denote the height of the triangle $\Delta \mathrm{UHK}$ as $k$ and half of the side of the triangle $\Delta \mathrm{UHK}$ as $h$ (see Figure 6), we can express these lengths for each type of Serlio's constructions. We can also express the length of the minor axis

$$
b=a+\sqrt{h^{2}+k^{2}}-(h+k) .
$$

In the construction in Figure 5a), we can approach two ways. The first is determining the length of the minor axis $b$, thus finding the length of the triangle side $2 h$.

The second is determining the length of the side $2 h$ of the triangle $\Delta \mathrm{UHK}$ and calculating the length of the minor axis $b=a+h(1-\sqrt{3})$.

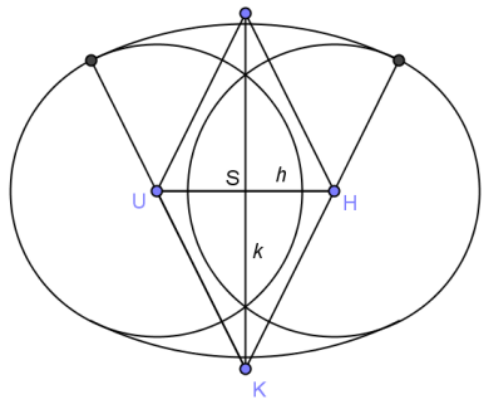

Fig. 6. Construction of two-centre oval, based upon Serlio's treatise redrawn by Holešová.

$\triangle \mathrm{UHK}$ is the equilateral triangle for the construction of the Fig. 5 a) and when we know $a, b$ is $h=\frac{a-b}{\sqrt{3}-1}, k=\sqrt{3} h$. When we have two squares as in Fig. 3b) is $h=k=\frac{a}{\sqrt{2}+1}$, $b=a(5-3 \sqrt{2})$. For Fig. 3c) is $h=k=a / 2, b=\frac{\sqrt{2}}{2} a$ and in case Fig. 5 d) is $h=a / 3$, $k=\sqrt{3} h, b=\frac{4-\sqrt{3}}{3} a$. 
Length (longer distance) of the chapel was chosen as the constant $2 \mathrm{a}$ to be applied as a basis for construction of all types of ovals, constructed after Serlio. Resulting ovals were positioned on the plan of the chapel, see fig. 7.
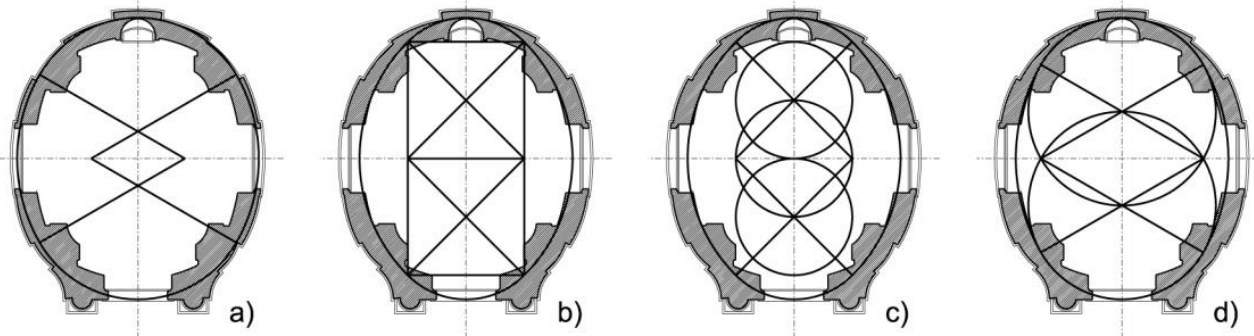

Fig. 7. Comparison of resulting oval construction after Serlio (fig.5) to the actual plan of the Chapel in Klačno, using length of chapel as $2 \mathrm{a}$ (double major axis) as a defining base. Drawing by authors.

\section{Conclusions}

Hypothesis A Ellipse - construction is simple, but not easily applicable on building site maybe on small scale, on larger scale is not applicable at all. If similar drawing method would be used on building site of the Palesch family Chapel in Kl'ačno movable board with drawing point $\mathrm{M}$ would had be almost $6 \mathrm{~m}$ long.

Hypothesis B Mandorla based construction - easily executable, but highly complicated one, therefore it is much less probable that it would be the first choice for a small scale design of the Chapel (and no visible mention in the form of inscription of symbolism on the Chapel itself or in the chronicle is found by research so far).

Hypothesis C Oval based construction - comparison on the fig.7. clearly shows that three of Serlio's methods result in too narrow ovals to be applicable on the chapel's plan. The first construction is much more flexible, so it is possible to use reverse-engineering to find the most suitable pair of equilateral triangles.

Three main ways of possible construction method were chosen and those divided to method of construction "on a paper" and on the building site. Chapel could be designed using "true" ellipse construction, mandorla based, heavily symbolic construction and by oval based construction method. Comparison of hypothesis A, B and C shows the logical conclusion two of the methods $\mathrm{A}$ and $\mathrm{B}$ are too difficult, rather complex, therefore not easily repeatable, and un-practical to construct on the building site. Serlio's constructions method were certainly known to builder and designer of the chapel as a common practice. They are easily executed and method fig. 5 a) and fig. 7a) oval is the most probably used.

Further analysis of the chapel in Kl'ačno will concentrate on finding more connections of Georg Palesch to possible architects - probably foreign or builders in the region with aim to find if possible original documentation. The second aim will be to make comparison as broad as possible to similar historical buildings in Slovakia with the goal to find possible used methods of construction known in the first half of 19th century. 


\section{References}

1. List of the houses in Nitra region, in latin, 1598. Archive of Magyar Nemzeti Levéltár Budapest, Magyar Kamara Archívuma. Sectio E 158, nr. 37. (slovak, latin) Published in: Štúdie o dejinách/Historia Nova 6, STIMUL 2013. ISBN 978-80-8127-082-6.

2. Mentioned as Paul Henrik Pales (1756-1835) in: Szinnyei József: Magyar írók élete és munkái XIII. (Steiner-Télfy). Budapest: Hornyánszky. 1909. (hungarian) [online] Available at: http://mek.oszk.hu/03600/03630/html/index.htm

3. Palles, Georg. Österreichisches Biographisches Lexikon und Dokumentation 18151950, Bd. 7 (Lfg. 34, 1977), S. 304. ISBN: 978-3-7001-3213-4 [online] Available at: http://www.biographien.ac.at/oebl/oebl_P/Palles_Georg_1753_1833.xml

4. Spišská Kapitula: Matrica Defunctorum 1819-1843, page 62. (latin)

5. Lacko, R. - Strečanská, Z. - Struhár, M.: Kl’ačno : 600 rokov prvej písomnej zmienky o obci : monografia obce, Martin, FOMI, 2013. ISBN: 9788097022679, p. 152. (slovak)

6. Archive of the Banská Bystrica dioceze, book of official documents facsimiles, 1824, page 242 .

7. Kollárová, R. - Grúňová, Z. - Žiak, J.: Architectonic-historical and art-historical research of the Slovak national monument, Chapel of Virgin Mary in Kl'ačno, 2016. (slovak). Unpublished research.

8. A. Becchi, D.B. Meli, E. Gamba, Guidobaldo del Monte (1545-1607): Theory and Practice of the Mathematical Disciplines from Urbino to Europe, 380 (epubli Berlin, 2013)

9. S. Serlio, Il primo [-secondo] libro d'architettura, (Venice, 1545) (italian). [online] Available at: https://archive.org/details/gri_33125008448702 